\title{
RECENT STUDIES OF THE MORPHOLOGY OF THE NEURONE IN HEALTH AND DISEASE ${ }^{1}$
}

\author{
BY
}

\section{J. G. GREENFIELD}

From the Pathological Department, National Hospital, Queen Square, London

(ReCeived 6TH April, 1938)

\section{Normal Neurone}

THE modern conception of the structure of the neurone is founded mainly on the work of Cajal and of Nissl. Earlier observers, such as Waller, His, and Ranvier, had established the connection of the axone with the nerve cell and paved the way for the neurone theory, which was formulated almost in its present form by Cajal (1891) on the basis of purely morphological study. To his method of impregnation with reduced silver nitrate we owe our knowledge of the neurofibrillar structure of the neurone and of its reactions to injury or disease. Modern knowledge of the changes in the structure of the nerve cell in disease is, however, chiefly based on Nissl's studies by his polychrome methylene blue method. His classification stands to-day with minor modifications as the basis of neuronal pathology. The end of the life-work of Nissl and Cajal, therefore, forms a convenient starting-point for a survey of recent studies on the morphology of the neurone. It will be convenient first to examine the normal structure of the neurone as indicated by these researches, and secondly to review additions to knowledge of the changes which the neurone undergoes in disease.

\section{The Perikaryon}

Physical Constitution.-The examination of the fresh nerve cell with the ultra-microscope by Marinesco (1911) and Mott (1912) did not reveal any constituents which other methods had not shown. Rather, it made them cast doubts on the existence of Nissl granules and neurofibrils in a preformed state. It seemed to them that these structures could not be brought out without special staining technique and were to that extent artefacts. To-day, however, the existence of these structures in the living neurone may be considered as definitely established.

The physical constitution of living cells has been recently investigated by de Renyi (1931) and by Beams and King (1935). De Renyi studied the anterior horn cells of the frog, removed immediately after death, by the technique of micro-dissection. His researches on the nerve cell carried him no farther than to demonstrate the extremely high viscosity and toughness of the structure of

${ }_{1}$ The substance of this article formed the basis of the Oliver-Sharpey Lectures delivered before the Royal College of Physicians, London, in March, 1938. 
the nerve cell. Thus if its opposite poles were transfixed and pulled away from one another, the cell tore across, leaving an irregular line of cleavage which remained unaltered for a short time, so that if the two halves were brought together again the anfractuosities of one-half fitted perfectly into those in the other, and the original outline of the cell was restored. Even the nucleus could be torn across and reconstituted in this manner. In addition, he was able to demonstrate the firm adhesion both of the dendrites of surrounding cells, and also, as he thought, of the neuroglial fibres, to the surface of the perikaryon, for it was very difficult to dislodge them with a jet of saline.

Beams and King have studied the physical properties of the nerve cell by the method of ultra-centrifugalization. Ingvar (1923) had studied the nerve cells of the mouse's brain by centrifugalization, but the length of time needed to cause more than minimal change at the speeds then available vitiated the results, as artefacts and post-mortem changes occurred. With the ultracentrifuge more effect could be obtained after ten minutes than after an hour with the older instruments, and Beams and King considered that the changes which they found were influenced only to a slight degree by autolysis. In the cells of the spinal ganglion of the white rat they were unable to displace the nucleus from the centre of the cell, and therefore considered that it had the same density as the cytoplasm. The constituents of both nucleus and cell body could, however, be displaced. The nucleolus moved to the distal pole of the nucleus and became flattened against the nuclear membrane ; the other basophil structures in the nucleus (nuclein threads and granules) also became displaced to the periphery. The shape of the nucleus became altered by stretching in the direction of centrifugal force, so that it became cylindrical or shaped like an hour-glass. The contents of the nucleus lay in thin layers, most peripherally the nucleolus, next the chromatin filling about half the nucleus, and proximally a clear area of nuclear sap. In the perikaryon the Nissl granules were found to move in the direction of centrifugal force, usually retaining, at least during the earlier phases, their discrete character and ultimately becoming piled against the peripheral part of the cell membrane. The cytoplasm remaining in the proximal pole of the cell was slightly granular and strongly acidophilic.

“Boutons terminaux."-Fedorow (1935) has observed the living nerve cells in the superficial plexus of the frog's heart by the method of Gramenitzky (1934). Using a water-immersion lens bathed in Ringer's fluid he was able to study the cells in a state as nearly physiological as possible. He also observed their alterations under conditions of acidity and alkalinity, hypertonicity and hypotonicity of the fluid they were bathed in, with or without the addition of vital or supravital dyes. Under normal conditions it was possible to see small granules or drops attached to nerve fibres on the surface of the nerve cells and these were proved by vital staining with methylene blue to be "boutons terminaux." In the nerve cells nothing could be seen except the nucleus and pigment granules, the latter varying in number with the season of the year, being most numerous in winter. His most interesting observations bore on the effect of physico-chemical changes in the fluid which bathed the nerve cells or of the $p \mathrm{H}$ of the serum. He was able to correlate these effects with those 
produced by mechanical injury or prolonged electrical stimulation. He observed two different types of early change in the "boutons terminaux," one which he termed "gelatinization," in which the discs became more sharply delimited and more intensely refractile, the other characterized by "swelling" of the discs, in which they became more rounded and transparent. "Gelatinization," which was reversible in its early stages, was produced by acidity, hypotonic solutions, and prolonged electrical stimulation of the vagus, and was also seen as a passing phase of degeneration following vagal section. It was usually associated with the appearance of granules in the cell body. The change described as "swelling," which always appeared to be irreversible, was produced by alkalis and hypertonic solutions.

The most important result of his work has been to establish the " boutons terminaux " as structures visible round the living nerve cell and showing during life the same appearances of degeneration (e.g. after section of the axone with which they are connected) as have been demonstrated in stained specimens. The degeneration of " boutons terminaux" affords a method of studying the terminations of nerve fibres and tracts, in relation to motor or sensory nuclei, which has recently been used with some success. Any observations, therefore, which give us more knowledge of their structure and of its variations under known conditions are of importance.

Pre-existence of the Neurofibrillar Network in Living Nerve Cells and Fibres. -The question of the existence of neurofibrils in the living nerve cell and fibre has excited much controversy. It has been known for some time that in certain lower forms, such as the jelly-fish, the crab, lobster, and torpedo, neurofibrils can be seen in fresh, unstained nerves. Kedrowski (1935) studied them in the antennæ of young living crustaceans (Branchipus, chirocephalus, apus), in which they appeared to be constantly moved about by the movement of the cytoplasm surrounding them. In these species the neurofibrils were seen in the bipolar nerve cells as well as in the nerve fibres arising from them. De Renyi (1929) saw them as a central core in the axis cylinders of the large nerves to the claw of the lobster, although he was unable to see them in frog's nerves ; and he argues from this that they are actually present in vertebrate nerves, but that owing to their finely filamentous structure, to their close juxtaposition in the axone, and to the comparatively slight difference in refractile power between them and axoplasma, they cannot be seen under the microscope. Weiss and Wang (1936) and Levi and Meyer (1937), independently, have seen them in tissue cultures from the nervous system of 11-14-day chicken embryos. Especially when the nerve cells in spreading out from the explant became isolated and somewhat flattened was it possible to see a definite fibrillar structure in the cell body consisting of fine concentric lines converging on the axis cylinder hillock and traceable into the proximal part of the axon. In the more peripheral part of the axone in which neurofibrils are presumably more closely set, they were not visible, nor were they seen in younger embryos and in earlier stages of tissue culture. Their appearance agreed with that seen after staining by Cajal's method, but varied in the same cell from day to day. In "younger" (Weiss and Wang) or "smaller" cells (Levi and Meyer) they lay in the peri- 
nuclear zone of cytoplasm, leaving a clear zone between them and the cell membrane, and it was found that the mitochondria (or Janus green granules) lay altogether in this clear zone.

Levi and Meyer also studied the degenerative changes which the neurofibrils showed in cells in old cultures. In such cells the fine fibres ran together into coarser lines resembling those seen by Tello (1904) in hibernating lizards, and in mammals exposed to cold (Cajal, 1904 ; Donaggio, 1906). In more severely degenerating cells the neurofibrils were collected together in a clump of densely compressed fibres prolonged into the axis cylinder and were easily seen against the background of clear cytoplasm. These appearances closely resembled those seen in degenerated spinal root ganglion cells under a variety of conditions. The evidence which these experiments give as to the existence of neurofibrils in normal living vertebrate nerve cells may not be completely convincing, but they agree completely with de Renyi's theory that our inability to see neurofibrils in living axones is due rather to the imperfections of microscopical definition than to absence of preformed fibrillar structure in the nerve cell and fibre.

By photography with ultra-violet light Weimann (1925) was able to demonstrate in fresh nerve cells and their processes a network of fine threads which ran through, as well as between, the Nissl granules. There was no suggestion that the threads were made up of rows of rods and granules. Thenon and Pirowski (1937), using the same method, could not demonstrate any structure resembling neuro-fibrils. Both they and Weimann obtained beautiful pictures of Nissl granules in fresh nerve cells.

Mineral Composition.-The method of microincineration has been used during recent years to demonstrate the mineral composition of different tissues. It was applied to nerve cells by Jacobi and Keuscher (1927), and by many since them. All are agreed that the appearances seen in ashed sections by oblique or dark-ground illumination agree remarkably with those obtained by Nissl's method. Mineral deposits are only seen in the nucleolus and Nissl granules; most of the nucleus, the neurofibrils, and the axone hillock appearing quite clear. The appearances seen by this method agree remarkably with those obtained by photographing nerve cells with ultra-violet light, and it has indeed been suggested that the opacity of different structures in a cell to ultra-violet light is related to their mineral content. The minerals in both nucleolus and Nissl granules are chiefly calcium, with less iron, and a trace of silica is aiso present in the nucleolus. Alexander and Myerson (1937, 1938), who have recently examined the nerve fibre by this method, find no ash in the myelin sheaths and only a trace of bluish ash which volatilizes at about $650^{\circ} \mathrm{C}$. in the axis cylinder. This may be magnesium. They found that the cells of the sheath of Schwann and the endoneurium of peripheral nerves contained mineral ash. In the central nervous system the nerve fibres left no ash, although lines of ash might be seen running along them which appeared to correspond to the processes of neuroglial cells.

Alexander (1938) showed that there was a considerable variation in the amount of ash left by different types of nerve cell. In general granule cells 
contained denser mineral deposits than the larger nerve cells, but variations were also seen between different collections of granule cells. Those of the cerebellar cortex and of the fascia dentata were particularly rich in ash, while those of the cerebral cortex were poor. Differences also existed between different regions of the cortex ; thus the pre-central gyrus contained much more ash than the post-central, and the basal ganglia were very poor in mineral constituents. This work indicated a new method of approach to the study both of normal and pathological nervous tissue which may prove of considerable value. The method, however, fails to show the distribution of magnesium, a metal in which the nervous system is particularly rich but which is sublimated by the temperatures needed to ash nervous tissue satisfactorily.

The Structure of Nissl Bodies.-While photography of fresh cells by ultraviolet light has settled the vexed question of the pre-existence of Nissl granules and micro-chemical methods and micro-incineration have determined their chemical structure, it still remained doubtful to what extent their appearance in stained sections was determined by the fixative used. Cowdry (1932), for example, recently stated that the size and shape of the granules depended on the composition of the fixative. Nissl and the German school have always insisted that no interpretation of the appearance of nerve cells by the Nissl method was satisfactory unless the material were primarily fixed in alcohol. On the other hand, in England it has long been considered that the appearances after fixation with formalin were identical with those seen after alcohol, and that a variety of stains, including various hæmatoxylin lakes, could be used to demonstrate the Nissl granules in addition to the basic blues used by Nissl.

The recent work of Einarson (1935) seems to have disposed of this question. Using the new dyes, gallamin blue and gallocyanin, he was able to stain Nissl granules after any form of fixative and found the pattern and form of the granules to be essentially the same whatever the fixative used. It was shown long ago by Mackenzie (1897), Macallum (1898), and others that the Nissl granules contained iron ; and the presence of nucleic acid was shown by the application of Feulgen's technique. Einarson found that the acid dye gallamin blue stained the cell diffusely, leaving the nucleus and Nissl granules unstained in material fixed in ammoniacal alcohol, whereas after fixation in neutral alcohol or formaldehyde or in any acid or acid combination of fixatives this stain gave a picture similar to that obtained by Nissl's method. He therefore concluded that there was in the Nissl bodies an acidophil substance as well as a basophil one. Further, he showed that 24 hours' washing in warm water after fixation in 96 per cent. alcohol removed part of the basophil substance, leaving the acidophil substance unchanged. From this work he formulated two conclusions. First, that in the perikaryon there are two substances in a colloidal state : $(a)$ a fluid which represents the dispersed phase and after coagulation forms the Nissl bodies, and $(b)$ a viscous semi-solid or plastic substance which forms the continuous phase and conditions the typical formation of the pattern of neurofibrils. Secondly, that the Nissl bodies have three constituents, a basophil chromatin substance, a basophil protein, and an acidophil protein. Of these, the first 
two are soluble in acids (and in sodium carbonate after fixation) and the second is soluble in warm water.

Mitochondria.-The presence of mitochondria in nerve cells was for a time disputed, but has been established by Cowdry $(1912,1914)$ and many recent workers who have applied the supra-vital technique with Janus green and other modern staining methods. The early failures to stain mitochondria selectively appear to have been due to the rapidity with which they disappear after death and to the need for special fixation for most of the histological methods. In normal cells they occupy the same position as the Nissl granules. Bertrand (1927) and Bertrand and Hadzigeorgiou (1928), who studied them by infra-red photography, found that they retained this position in chromatolysis and might even remain unchanged after the Nissl granules, disappeared, as for example in Landry's paralysis. Choja (1936) recently made an extensive study of the mitochondria and found considerable differences between nerve cells of different systems in the number of granules present. In general, the pyramidal cells of the cortex and the sensory nerve cells of the brain stem, spinal cord, and dorsal root ganglia contained more than the motor nerve cells of the brain stem and spinal cord ; the Purkinje cells of the cerebellum and the cells of the vagal nuclei contained abundant mitochondria, while the cells of the cornu ammonis were very poor in them. In inflammatory, toxic, and virus diseases of the nervous system, the mitochondria rapidly altered, becoming at first larger and more numerous, but soon shrinking and disappearing as the disease progressed. In many cases he found a tendency for a particular organism or virus to affect the mitochondria of particular groups or systems of nerve cells. Whether this "selective vulnerability" of the nerve cells is due to differences in the mitochondria or in some other constituent of the nerve cell is not, of course, shown by this study, since it is probable that mitochondria are to a great extent dependent on the general health of the cell. For example, Weston Hurst (1929) found in poliomyelitis that, although the mitochondria in the affected cells of the anterior horns disappeared less rapidly than the Nissl granules and might still be present in the earlier stages of neuronophagia, they did not survive the death of the cell. Marinesco (1930) and Bertrand and Hadzigeorgiou (1928) considered that mitochondria granules, by breaking down, gave rise to lipochrome. This view was based not only on similarity of chemical structure, but also on the observations of the latter workers that cells containing much lipochrome contained few or no mitochondrial granules. This relationship was specially noted in senile dementia and in amaurotic family idiocy. This theory is attractive, but more work is needed before the relation of these constituents of the nerve cell is finally established.

All this work has done little to alter the conception of the nerve cell formulated by Cajal and Nissl. Rather it has confirmed their work by indicating the presence in the living cell of structures which, allowing for the inevitable results of fixation, have the characteristics of the neurofibrils and basophil granules which they described. The modern conception of the nerve cell is that its protoplasm is remarkably firm and static, perhaps a pre-requisite for its long life. On the other hand, its cell membrane, if any exists, is extremely 
tenuous, a character no doubt related to the extremely high rate of metabolism which nerve cells have been shown to possess, and to their extreme vulnerability when their environment is altered.

\section{The Nerve Fibre}

Normal Constitution.-The axis cylinder in the peripheral nerves of the frog has been subjected by De Renyi $(1929,1932)$ to examination by the micro-dissection method. The living axone consists of thick internodal segments separated by short, thinner segments at the nodes of Ranvier. According to De Renyi, the diameter of the living axone is about seven times the thickness of the myelin sheath along the internodes. Nageotte (1911) had shown that under the action of various fixatives, such as silver nitrate and formalin, the myelin swelled at the expense of the axone especially in the internodal segments so that in preparations fixed in this way the nodal part of the axone became thicker than the internode. After fixation with osmic acid the appearances corresponded more closely to those seen in unfixed nerves. De Renyi explained this by supposing that under the action of the slower fixatives, fluid passed out of the axones into the myelin sheath along fine pores between the two. But that the connection of axone with myelin sheath was not very intimate was shown by experiments in which he either injected fluid between the two, or pulled the myelin sheath away from the axone. Under such treatment, the outer surface of the axone was revealed as a smooth membrane from which the myelin could be lifted up or peeled off. A valuable part of his experiments had to do with the structure of the node of Ranvier. Here, as has already been seen, the axone is thinner but firmer than in the internodal part, and is less changed by fixatives. These characters persisted when the axone was deprived of myelin and sheath of Schwann, and appeared to depend on a difference in structure of the axone itself at this point. By careful micro-dissection after fixation in silver nitrate he was able to divest the sheath of Schwann of its close investment of endoneurium, or sheath of Key and Retzius. When this was done the cement substance at the node was found to come away with the endoneurium, leaving the sheath of Schwann as a continuous membrane apparently of syncytial character, an appearance which agrees well with its behaviour in degeneration of nerves.

As to the relative thickness of axone and myelin sheath, much has been written in the past. Older writers (Donaldson and Hoke, 1905) considered that the areas on cross-section of the myelin sheath and of the axis cylinder were the same. This would mean that the diameter of the axone was about five times the radial thickness of the myelin sheath. These estimates were made from nerves fixed in osmic acid in which the relative thickness of myelin sheath and axone might have been altered slightly. Arnell (1936) attempted to study this in a more direct manner by cutting frozen sections on the chilled knife and transferring these directly to the slide, where they were examined either with or without fixation and staining. He found that the ratio of the area of axone to myelin sheath was on the average 1 to $3 \cdot 5$, but was very variable. The lowest ratio in all nerves was 1 to 1 ; the highest was 1 to 6 in the largest fibres, 1 to 15 in medium-sized fibres, and 1 to 12 in the smallest fibres. It seems 
doubtful, however, whether the method is sufficiently free from artefact for these results to be accepted at their face value, since it is unlikely that such great variation in the relative thickness of axone and myelin sheath exist in normal nerve fibres. It had previously been shown by Duncan (1934) that, except in the autonomic system, myelination was dependent on axone thickness, so that every axone in the spinal roots which was more than $1 \mu$ thick became invested with a myelin sheath. This observation may explain the large number of unmyelinated fibres in the peripheral nerves of smaller animals, such as the rat and cat, and their paucity in the human. So far, apart from some indication in the work of Arnell, there is little evidence that the relative thicknesses of myelin sheath and axone differ in nerve fibres with different functions.

The experiments of Perdrau (1937) on the diffusion of solutions up axis cylinders are of interest from the indications they give as to its physical nature. In the living rabbit, as well as in the excised nerve, he found that if the cut end of the sciatic nerve were bathed in Ringer's solution containing either methylene blue or acid fuchsin, the dye travelled up the axis cylinders at first rapidly, but afterwards more slowly, passing up a distance of 4 or $5 \mathrm{~cm}$. in about 4 hours. The largest fibres stained most easily, and the intensity of the colour diminished the further the dye travelled. With the perineurium intact and the end of the nerves sealed off, no staining of the axone was obtained, so that it was clear that the dye reached the axone at its cut end and passed along it. Kataphoresis was found to facilitate the passage of the dye, and after it the axone stained more deeply. If the nerve were bathed in a mixture of iron ammonium citrate and potassium ferro-cyanide the solution passed both up the nerve and along the connective tissue sheaths and, after fixation in acid formaldehyde, Prussian blue granules could be demonstrated in the cement substance of the node of Ranvier as well as in the axis cylinder. A picture closely resembling the cross obtained by Ranvier's silver method was thus obtained at the nodes.

A remarkable result was obtained when the iron ferrocyanide solutions were made by kataphoresis to travel up the nerve into the spinal cord. In these experiments many of the nuclei of the anterior horn cells were stained, leaving the nucleolus and the chromatin unstained. The nerve cells in the dorsal root ganglia, however, remained unstained. Perdrau had not suggested that the axone had a more direct relationship with the nucleus than with the perikaryon, but the analogy between his experimental results and the observations made by Hurst (1936) and others on the effects of neurotropic viruses on the nerve cell are striking (v. infra).

The axone may therefore be considered as a protoplasmic thread containing a more fluid part, the axoplasma, and fine, very delicate threads of a firmer consistence, the neurofibrils. The fact that slow fixation causes less shrinkage at the nodes of Ranvier than at the internodes is best explained by supposing that the axoplasma is less fluid in the nodes than in the internodes as it seems unlikely that the neurofibrils differ in consistency in different parts of the nerve fibre. That the axone is surrounded by a delicate membrane seems established by the work of de Renyi, but whether this membrane is derived from the sheath of Schwann, as in the older conception of the sheath, or whether it is an 
integral part of the axone remains undecided. The latter appears the more plausible hypothesis, as the character of the axone appears to be the same in the central nervous system as in peripheral nerves.

Nerve Regeneration.-The debatable ground between physiology and pathology, represented by the regeneration of peripheral nerves after section, was very fully explored by Cajal $(1913-14,1928)$, especially in the researches which he made in his later years to disprove, once and for all, the catenary theory of nerve regeneration. This subject has been studied in the living nerve by Peterfi (1931) and Speidel (1935), who used young tadpoles at a stage when their tails were sufficiently translucent to allow of microscopic investigation with high microscopic powers. Many details of possible variations from the usually accepted methods of regeneration were thus brought to light. Speidel emphasized the symbiosis of axone and sheath cell, showing that sheath cells which lost their nerve fibre rapidly disappeared. Whether this occurs in adult mammals is doubtful, as the band of Büngner is preserved for long periods after nerve section, and the rate of growth of new axis cylinder sprouts, when they reach the bands of Büngner in the peripheral segment of a cut nerve, does not appear to be reduced when regeneration is delayed for weeks or months. Speidel found that the growth of the axone might be stimulated by such factors as the proximity of the growth cone of another axone or by mitosis in the sheath cell or in a neighbouring myoblast, which might result in the formation of a lateral branch from the axone. He found in the living, as Dustin (1910) deduced from the study of fixed material, that the orientation of the growing nerve sprouts was largely determined by the growth of fibroblasts, the constant movement of which swayed the growth cone about or bent the axone.

Among the most interesting of his observations was that, in regenerating nerve fibres, myelin might be formed in an internodal segment separated from the normal nerve (from which the fibre arose) by one or more unmyelinated segments. Whether this is a usual process in the regeneration of human nerves has not yet been established. In a case of section of both the sciatic nerve and the popliteal artery by gunshot wound which I examined some years after the war, I found the unusual condition of regrowth of numerous axis cylinders into the peripheral segment of the nerves with little or no attempt at remyelination. This was attributed to the very inadequate blood supply to the peripheral part of the limb. It is thus possible that local conditions of nutrition may determine whether or not individual segments of regenerating nerve fibres become myelinated.

It is difficult to assess to what extent this mechanical or hydrodynamic theory of the orientation of nerve sprouts cuts across Cajal's theory of neurotropism, as Cajal accepted it as a partial explanation of the path taken by nerve sprouts in a stump neuroma or junction neuroma. In his later papers he considered that neurotropism, i.e. a chemical attraction by substances formed by the cells of the sheath of Schwann or band of Büngner, only came into play when the nerve sprouts approached the ends of these bands. There has been and can be little question that as soon as the nerve sprouts enter the band fibres they take on a much more rapid and harmonious growth. This has been shown repeatedly in human cases of nerve section and suture as well as in animal experi- 
ment. But the author's observation of human material, as well as a careful reading of the experimental results of Cajal and others, suggest that the word " neurotropism" is too strong for the factors at work, which seem to be more nutritive than attractive. It is clear that the growth of nerve sprouts is stimulated when they come into contact with or in close proximity to sheath of Schwann cells derived from the same animal or an animal of the same species, whereas their growth is inhibited by sheath of Schwann cells from other animal species and by most other kinds of tissue, whether homologous or heterologous. The point at issue is rather the distance at which this nutritive action works and whether the orientation given to growing nerve sprouts depends on a chemical attraction or on more mechanical factors.

Nageotte (1914) has demonstrated, and experience in cases of nerve section has repeatedly confirmed, the formation of outgrowths of "band fibre " nature from the peripheral cut end which may unite with nerve sprouts from the proximal end, or may form a stump neuroma which contains no nerve fibres. In either case the arrangement and direction of the outgrowths of band fibres appears to be determined chiefly by the fibrous and other tissues which surround them, and the junction of an empty band fibre with a nerve sprout seems to be determined largely by chance aided by the orientation of collagen fibres along lines of tension.

\section{Neurone in Disease}

Axonal Reaction

The well-known reaction of the nerve cell to injury or disease of its axone has been so thoroughly studied by Nissl that it would seem that little fresh could be gained in this field. Further studies have, however, added something to our knowledge of this reaction. Penfield (1920) applied Cajal's method for staining Golgi's internal apparatus to nerve cells after section of their axone, and showed that the changes in this structure were analogous to those in the Nissl granules, but differed in certain respects. For example, while the Nissl granules in the cells of the dorsal root ganglia showed little change after section of the dorsal roots, the Golgi apparatus was definitely altered. This change began on the 4th day and reached its zenith by the 7 th day after nerve section. In the anterior horn cells after section of the sciatic nerve it appeared on the 7 th day and had reached its maximum on the 12th day.

Nicholson (1923-4) studied the cells of the hypoglossal nucleus in rats, after section or tearing out of one hypoglossal nerve, by Macallum's hæmatoxylin method for iron, and showed that the masked iron in the Nissl granules disappeared along with the Nissl granules. The loss of chromophilic substance was thus associated with a change of chemical composition in the cell. When the hypoglossal nerve was torn out the iron disappeared gradually, first from the cytoplasm and later from the nucleus, so that by the 35 th day the cell was completely deprived of iron. Such cells were considered dead. In the less severe degrees of reaction iron appeared to pass from the nucleus into the cytoplasm of the cell, especially towards the axone hillock, but it never entered either the axone hillock or the axone itself. 


\section{Transneuronal Degeneration}

Further study has also recently been given to the question of transneuronal degeneration of nerve cells. Mott (1911) gave a negative answer to this question, stating that though " direct injury" of any part of the neurone would cause changes in it, injury of neurones with which it was functionally, but not nutritionally, connected would have no effect on it. When both sciatic nerves of an animal were cut and hemi-section of the cord also made, he could find no difference in the degree of axonal reaction on the two sides of the cord. This was in opposition to the previous findings of Marinesco (1909) and others. Recent work has, however, given indisputable proof that transneuronal degeneration may occur, at least in certain systems. Minkowski (1920) was the first to observe atrophy of certain cell layers in the external geniculate body after lesions of the optic nerve. He described the reaction as a shrinkage of the cell body without other evidence of degeneration. Le Gros Clark (1932) found a similar atrophy in a middle-aged woman two years after enucleation of one eye, and in a macaque monkey seven months after destruction of an eye. He describes the cells as shrunken and chromatolytic. With Penman (1931) he used this reactionary atrophy in experimental studies of the relations of areas in the retina to the cell layers in the external geniculate body. Horanyi Hechst (1933) and Balado and Francke (1937) have also observed laminar atrophy in the external geniculate body in cases of optic atrophy resulting from the pressure of tumours.

We are dealing here with cells which probably do not receive synapses from any neurones other than those coming from the retina, and which for that reason may be especially sensitive to lesions of the optic nerve. But Foerster and Gagel (1934) after section of the dorsal roots have demonstrated a chromatolytic reaction in the secondary afferent neurones of the spinal cord as well as in the motor cells of the ventral horns and in the intermedio-lateral tract. The demonstration of degenerating "boutons terminaux" round the same neurones proved that they were in direct synaptic connection with the primary sensory neurones. This transneuronal reaction was found to begin 6 days after section of the roots, and might still be visible 6 months later. These neurones, at least the ventral horn cells and the intermedio-lateral tract, are in connection with one or more neurones other than those severed by the operation. A similar reaction in the ventral horn cells may sometimes be seen in cases of cerebral tumours involving the precentral convolutions. It is probably much more common than has been supposed, and it may be of considerable importance in human pathology, for example in the pathogenesis of system diseases such as amyotrophic lateral sclerosis and the cerebellar degenerations. The swelling of the cells of the inferior olive after lesions of the central tegmental tract in the pons, described by Foix, Chavany, and Hillemand (1926) and others, is a case in point.

\section{ISCHÆMIA AND ANOXÆMIA}

Ischarmic Changes in the Nerve Cell.- “ Ischæmic " changes in the neurone are such common and well-known findings in human pathology that they 
would seem scarcely worthy of discussion were it not that some controversy has arisen on the interpretation of histological changes found in certain diseases as due to anoxæmia. In human pathology it is obvious that the effects of post-mortem autolysis must be the same as those of the earlier stages of ischæmia, and consequently the greatest care has to be taken in the interpretation of these changes. In animal experiments another complicating factor arises. It is common knowledge that when animals are killed and their nervous system placed in fixative within a few minutes of death, the nerve cells, especially in the cortex, assume two very different forms : some appear swollen and pale, others shrunken and hyperchromic. It is assumed that these differences depend on the state of activity of different neurones at the time of death. In reviewing the literature of experimental work it is remarkable how frequently this normal finding has been interpreted as being related in some way to ischæmia, and in consequence many of the results must be accepted with caution.

There is little doubt that Nissl's " chronic cell change" may be produced by ischæmia, though whether this is its only cause may be open to question. Gildea and Cobb (1930) and Tureen (1936) have made fresh experimental studies, and their results, especially those of Tureen, are of considerable interest. All experimenters have shown that there are considerable differences in the resistance of different nerve cells to ischæmia. Gomez and Pike (1909), for example, gave the following order of vulnerability : (1) the smaller pyramidal cells of the cortex ; (2) the Purkinje cells ; (3) the cells of the medulla, retina, and spinal cord ; (4) cells of the spinal root ganglia. As to the duration of complete cessation of blood flow required to produce any lasting change in the nerve cells, there is less certainty as it is probable that in all experiments on the brain a very slight flow of blood is still present in the cortical capillaries. Gildea and Cobb observed such a flow ophthalmoscopically in their experiments, however many of the main vessels to the head and neck were obstructed. They concluded, however, from their own experiments and those of Ford (1928), who had used the method of replacement of oxygen by nitrogen, that the cortical neurones may be irreparably damaged after 5 minutes of anoxia or severe ischæmia. The medullary neurones may survive up to 20 or 30 minutes of almost complete cessation of blood supply, and according to Tureen (1936) complete stoppage of the blood flow to the spinal cord may be recovered from if it lasts less than 20 minutes. In addition to the well-known " chronic cell change" of Nissl, Gildea and Cobb describe an early stage in which the nerve cells stain diffusely and have spike-like dendritic processes, and a later stage, only seen in animals surviving for 48 hours or more, in which the nerve cells appear somewhat swollen. Although liquefaction of nerve cells was never seen, many of the cells, particularly those of the third and fourth cortical layers, had disappeared in 24 hours after temporary ischæmia, producing " areas of devastation" or "areas of pallor" which were identical with those on which Spielmeyer (1930) has laid so much emphasis in human pathology.

Tureen's experiments were conducted on the spinal cord of cats. He found that when he clamped the thoracic aorta just below the arch and then injected 
neutral red into the circulation, there was no staining of the lower thoracic and lumbar cord, thus showing that the blood supply to these areas had ceased. In a large series of experiments the aorta was clamped at this level for periods varying from a few minutes up to $1 \frac{1}{2}$ hours, and the animals were kept alive for from 1 hour to 4 months. He found that all animals in which the aorta was clamped for 20 minutes or longer remained permanently paralysed in their hind legs, whereas those in which it was clamped for 15 minutes or less recovered within 24 hours. The sequence of changes in the motor neurones of the lumbar cord was carefully studied in these animals. The nerve cells were all affected, though the degree of change might not be the same in all. In the experiments in which the animals recovered, extensive loss of Nissl granules was seen 7 hours after the experiments. The cytoplasm stained deeply, and contained an amorphous deposit, with occasional traces of Nissl substance near the periphery of a few cells. Many of the nuclei stained deeply. At a rather later stage (28 and 36 hours after the experiment) the cell body and dendrites stained darkly ; the nuclei were still more deeply stained and might be eccentric. Some cells had a globoid shape, others retained their normal outline. At a rather later stage ( 48 hours) neuronophagia of some of the nerve cells could be seen. It is noteworthy that these changes were present at a time when all evidences of paralysis had passed off. Reparative changes in the neurones first made their appearance after about 72 hours, in a gradual reappearance of Nissl granules, usually first in the periphery of the cell. After 6 days the nerve cells had almost regained their normal appearance, but stained rather deeply ; at later stages they differed in no way from those of normal control animals. Of the experiments in which permanent paralysis was produced, those with 30 minutes' obstruction of the aorta were specially interesting. From 1 to 12 hours after these experiments, Tureen found swelling and rounding of contour in all the nerve cells. In the early stages this resembled the " acute swelling" which Marinesco (1909) had described in similar experiments; it disappeared in 24 hours and was replaced by the shrunken hyperchromic appearance commonly associated with ischæmia.

These experiments appear to have been well controlled, and present an even series in which the results were predictable within certain limits. They are therefore important as indicating the degree of ischæmic change in ganglion cells from which complete recovery can take place. It is noteworthy that in the experiments with recovery of function the nerve cells showed neither early swelling nor later shrinkage, although the diffuse staining seen in the severer degrees of ischæmic degeneration was well marked.

In a later study of these spinal cords by the micro-incineration method Tureen (1938) observed alterations in the mineral deposits in the nerve cells which could not be fully correlated with the changes seen by Nissl's method. In the experiments in which the aorta had been compressed for only 15 minutes there was a progressive increase in minerals both in the nucleus and in the cell body, especially towards its periphery. This attained its maximum in 36 hours and persisted for 2 weeks or longer. In the experiments in which the ischæmia was continued for 20 minutes or more, a transitory stage of hypermineralization 
gave way after $1 \frac{1}{2}$ hours to a stage of progressive loss of minerals, so that at the end of 13 hours the nerve cells might contain no more minerals than the surrounding tissues, although in some cells irregular dense deposits of minerals were seen even in the later stages of cell dissolution.

In human pathology the slighter recoverable changes in nerve cells are difficult to distinguish from the results of post-mortem autolysis. But when they are found in limited areas related to an obstruction of the blood supply, either on the arterial or venous side, they are significant. Changes of this character, as well as of more severe degree, may be seen, for example, in the cortical nerve cells near a thrombosed cortical vein, in an area where the blood flow is greatly retarded. The more common result of ischæmia in human pathology is the disappearance of nerve cells which leave no trace except an overgrowth of neuroglia and microglia. This is often seen in localized " areas of paling" in the fourth and fifth layers of the cerebral cortex and characteristically also in Sommer's sector in the cornu ammonis. When Purkinje cells disappear in this way, as they often do, the phagocytic glial cells are arranged along the dendrites in an arrangement to which Spielmeyer gave the name "glial bush arrangement" (Glia-strauchwerke).

These local disappearances of nerve cells are so commonly seen in epilepsy that they have been considered characteristic of the disease, although they may also occur in poisoning from carbon monoxide and nitrous oxide and have been described as occurring in cases of hypoglycæmic coma without convulsions. All these conditions are akin to ischæmia in that they interfere with the metabolism of the nerve cell. Whether in epilepsy the death of nerve cells should be ascribed to the intense congestion and capillary stasis which occurs during the fit or to a spasm of small vessels accompanying it is at present an open question. Spielmeyer (1930) has remarked that the areas which are especially liable to be affected derive their blood supply from rather long, fine vessels which lack the rich anastomosis which is present in less vulnerable areas of the cortex.

Ischamic Changes in the Nerve Fibres.-Ischæmic changes in the nerve fibres have not been so fully studied experimentally, although they are well recognized in pathology. Tureen's observations on the spinal cord would indicate that the axones are less vulnerable to ischæmia than the cell body, as he did not observe any softening or degeneration in the white matter of the cord in his experiments. The local vacuolar swellings in the lateral columns of the spinal cord which are commonly seen in cases of epidural tumour are more likely to be due to ischæmia than to direct pressure, as their appearance is similar to that seen at the margins of the softened area in cases of thrombosis of the posterior inferior cerebellar artery. They usually lie at a little distance below the surface in the lateral columns, although they may occur further forward. They appear to occur very rarely in the dorsal columns. Quite frequently they are related to a small vessel. They are most often seen in cases in which paraplegia has recently become fairly complete and probably represent the most severe effects on the cord of an ischæmia which is interfering considerably with the function of all the tracts. 


\section{Cerebral Gdema}

Closely related to ischæmia is the problem of œdema, and from the point of view of pathogenesis any sharp distinction between them is artificial, since œdema also probably interferes with the oxygen metabolism of the neurones. It is not surprising, therefore, to find similar changes in the nerve cell in œdematous areas of the cortex as are seen in the milder grades of ischæmia. Most often the cells are shrunken and stain homogeneously, showing a minor degree of Nissl's chronic cell change. The more severe degrees of this change from which recovery is impossible are less often seen.

The writer has recently, with M. L. Miller, studied the effects of œdema on the white matter of the brain. Local œdema, such as is seen near a tumour or abscess of the brain, appears to affect the centrum semi-ovale more than the cortex. Its effects are certainly more obvious in the white matter, and often cease near the cortex, sparing the subsulcine layer of fibres. These effects consist not only in a separation of the nerve fibres from one another, but in a general impoverishment of the myelin sheaths, which tend to be irregularly beaded and show here and there "sudanophil" droplets. When œdema is very marked, as after severe injuries with fracture of the skull, areas of complete demyelination may be found. This is unusual, but in all except the mildest grades the area of œdema is demarcated in Weigert-Pal preparations by a diffuse pallor which cannot be altogether attributed to separation of the nerve fibres by interstitial fluid. While the myelin suffers obvious and irreparable damage, the axones do not escape, but show varicosity, irregularity of outline, or the formation of end-bulbs in varying degree. These changes for the most part seem to disappear along with the œdema. They are at least much more obvious in œdematous areas than in areas showing pallor of the myelin from which the œdema has disappeared. The local areas of demyelination of the centrum semiovale, which may be found months or years after a severe cerebral contusion, are probably attributable more to the œdema which follows the injury than to the blow itself, although the local bruising of the cortex will entail some loss of fibres underneath it and hæmorrhage into the white matter may account for some loss of myelin.

\section{AvitAMINOSIS}

The neurone is particularly liable to be affected in conditions of avitaminosis. It would probably be wrong to consider that lack of any of the known vitamins affects the neuron alone, since in every case there seems to be some disturbance in general health. But the complex known as vitamin B appears, from the work of Peters (1936) especially, to be so closely linked with the metabolism of the nerve cell that its absence leads rapidly to a loss of function and, at a later stage, to changes in the structure of the nerve cell and fibre. The relation of the thermolabile factor B1 to degeneration of the peripheral nerves is so well known as hardly to call for comment were it not for the very careful and detailed observations which have recently been made by Bertrand, Liber, and Randoin (1934). These authors fed pigeons on a carefully balanced diet deficient only 
in B1 and killed them for histological study at various stages of the resulting paralysis. They found that the changes in the nervous system were confined to the peripheral parts of the sensory-motor nerves, the unmyelinated autonomic nerves remaining intact. They describe three types of parenchymatous change in the peripheral nerves : (1) one in which the axis cylinder appeared to be primarily affected ; (2) a simultaneous change in the myelin sheath and axon associated with separation of the myelin sheaths from one another at the nodes of Ranvier ; and (3) a form in which the most striking feature was the formation of varicosities and buds in the contour of the myelin sheath. Up to a certain stage these changes were comparable to those seen in Wallerian degeneration ; but after the early stages in which the myelin began to stain with the Marchi method, little further katabolism of myelin took place. Thus at the stage when it had broken up into hollow balls (containing fragments of axon), there was still no tendency to stain with Sudan. This delay in katabolism, after the fragmentation of the axon, was associated with a remarkable quiescence of the cells of Schwann, which did not form Erzholz bodies or undergo mitotic division and apart from a moderate increase in the amount or protoplasm remained inert. Nor was there any invasion of the nerve fibre by mesodermal phagocytes. When vitamin B1 was added to the diet the picture rapidly changed. The sheath cells underwent mitosis and increased in number, and phagocytic cells invaded the nerve fibre in which the lipoid droplets had become Sudanophil. It appeared likely that the arrest of katabolism of myelin at the pre-Sudanophil stage was due to a direct metabolic disturbance in the cells of the sheath of Schwann rather than to any change in the composition of myelin induced by lack of vitamin B, otherwise it would be difficult to explain the rapid appearance of the usual picture of Wallerian degeneration after treatment.

This failure of activity in the sheath cells may be compared with a similar inactivity in them, amounting sometimes to necrobiosis, observed by de Villaverde (1926) in experimental lead poisoning.

The relation to nervous disease of the thermostable fraction of vitamin $B$ (B2 or G) has never been so clear as that of vitamin B1. Goldberger and his associates (1928) produced in dogs a diseased condition associated with black tongue which they thought was closely similar to human pellagra, but they did not reproduce the nervous lesions of the human disease. Stern and Findlay (1929) in rats produced a similar condition associated with lesions of the epidermis and some degree of paralysis, but without definite changes in the peripheral nerves or tract lesions in the spinal cord. Zimmermann (1937), however, by a carefully balanced diet from which vitamin B2 was excluded, produced in dogs a subacute or chronic disease associated with loss of weight, vomiting, and diarrhœa, and great muscular weakness and ataxia, but without " black tongue." In dogs on Goldberger's diet which developed "black tongue " only slight degeneration was found in the peripheral nerves and dorsal columns in the animals that lived longest. But in the more chronic disease the degeneration was very marked, both in the peripheral nerves and dorsal columns. The similarity of these changes to those seen in cases of pellagra is further 
evidence of the relation of this disease to lack of vitamin B2, although several differences between the human and the experimental disease still remain. For example, Zimmermann insists that the anterior horn cells and Betz cells in his dogs were normal, whereas in the human disease the latter cells constantly suffer, along with many other cortical pyramids, from the chromatolytic changes which Adolf Meyer called "central neuritis." On the other hand Stern and Findlay found changes in the neurones, but none in the tracts of the cord or peripheral nerves in rats deprived of $\mathrm{B} 2$ vitamin.

In the human disease the long tracts of the cord may or may not be affected. Usually the dorsal columns are more affected than the antero-lateral columns, but in a case reported by Langworthy (1931) the reverse was the case. In the specimens examined by the writer the degeneration appeared to differ from that of subacute combined degeneration in showing very little evidence of vacuolation in the early stages. It seemed to be a true Wallerian degeneration, and in the dorsal columns was related to degeneration of the entering spinal roots. In some of Pentschew's (1929) cases in which the duration of the illness was longer, asymmetrical areas of sclerosis were found on the margins of the antero-lateral columns.

The relationship of vitamin A to diseases of the nervous system is less clear, although certain observations lend strong support to it. Mellanby (1931) seems to have been the first to produce definite degeneration of the spinal cord in dogs by diets deficient in this vitamin. He found that a more rapid development of paralysis and more definite changes in the spinal cord were seen when, along with deprivation of $\mathrm{A}$, the animals were given whole wheat or rye. Still earlier and more striking evidence of cord degeneration was obtained by the addition of ergot to the diet, an observation which falls well into line with the well-known occurrence of degeneration of the spinal cord in epidemics of ergotism during years of famine. These results have been confirmed by Zimmermann and Burack (1934) in young white rats, which, in addition to the loss of weight found by all observers in rats deprived of vitamin A, suffered from inco-ordination and sometimes paralysis of the hind limbs. In these animals they found degeneration of both sciatic nerves and brachial plexus, in the dorsal, and sometimes in the ventral, roots and in the dorsal columns and the margins of the ventro-lateral columns of the cord. The degenerations in the spinal cord were not cured by carotin, nor did this substance prevent them unless given in adequate doses from the beginning of the experiment.

Eveleth and Biester (1937) have observed a disease in swine called " posterior paralysis" and associated with myelin degeneration in the cord and peripheral nerves. These animals were on a diet in which vitamin A was low, but was not completely absent. They have confirmed Zimmermann's observation that once paralysis had set in it was not cured by cod-liver oil. But in reviewing the evidence they were not satisfied that the degeneration in the cord was due entirely to a lack either of vitamin A or of the vitamin B complex, and postulated, as Mellanby has done, some toxic or positive factor as well as lack of vitamins.

In other food-deficiency diseases in which the spinal cord undergoes degeneration we are on less certain ground, as it is not known to what extent one 
of the known vitamins may be at fault in addition to the food element which is potent in curing the disease. In this country the most common of these is subacute combined degeneration of the cord. There is so far no certain evidence that this condition ever occurs apart from a megaloblastic anæmia curable by liver or liver extract, i.e. Addisonian anæmia, and it has become increasingly evident during the past few years that preparations of liver, if given in sufficient dosage, produce amelioration often amounting to cure of the nervous symptoms.

The degeneration in the spinal cord appears to affect the myelin earlier than the axis cylinders, although the latter never escape degeneration for long. It consists in the early stages of fusiform swellings of the nerve fibre in which the myelin is stretched round a vacuole which forms between it and the axis cylinder. At this stage the myelin retains its double refractility with a myelin cross and stains well by hæmatoxylin lakes. More than one swelling may be seen on the course of a nerve fibre in longitudinal sections. The axones may lie centrally or toward one side of the vacuole and often show varicosities or irregular swellings, presaging early dissolution. But it appears that if the disease is arrested at this stage or even after actual katabolism of myelin has begun, the axis cylinder may recover so that naked axones may be seen in sclerotic areas. The degeneration of the central parts of the dorsal columns described by Michell Clarke (1904) in pernicious anæmia appears to be the commonest early stage of the disease (Greenfield and O'Flynn (1933)). That the peripheral nerves are also affected in most, if not in all cases, was suggested by Russell, Batten, and Collier (1900) in their classical paper, and was confirmed by Greenfield and Carmichael (1936). The latter found in the terminal nerve twigs to the toes a condition of loss of myelin, apparently without corresponding lesions of the axis cylinders and without any of the severe degenerative changes commonly seen in polyneuritis.

Our knowledge of this curious disease may be carried a stage further by evidence gained from a similar condition which has been found in monkeys in captivity by Perdrau (1930) and Hamerton (1936-7) in this country, by Levaditi, Lepine, and Schoen (1930) in France, by Schob (1931) and Scherer (1932) in Germany, and by Davison (1934) in Germany. In these monkeys either the spinal cord or the brain or both may be affected, and in some animals there has also been degeneration of the optic nerves. Degeneration of the white matter of the brain in the form of discrete patches has been observed in many cases of subacute combined degeneration, but in that condition it is rare and seldom severe. For this reason the degeneration found in the brains of monkeys was at first thought to resemble most closely the lesions of diffuse sclerosis or Schilders disease. But both Hamerton and Scherer (1937), who have been able to study many examples of varied severity at all stages of the disease, have no doubt that it is most closely allied to subacute combined degeneration of the cord. That it may be caused by a vitamin deficiency or unbalanced diet is suggested by Scherer's monkeys, in which the nervous symptoms came on after a severe epizootic of diarrhœa or dysentery from which many died.

Whether the degeneration in the spinal cord of these monkeys shows a histological picture identical with that seen in subacute combined degeneration 
remains unsettled. It has been too readily assumed that all forms of combined degeneration of vacuolar type which show little tendency to be limited to definite tracts in the cord must be closely related to one another, both in their finer histological details and in their ætiology. In the present state of our knowledge that assumption does not seem altogether warranted. Nor should the analogy between "cage paralysis" and subacute combined degeneration of the cord be over-stressed. The monkeys do not all have achlorhydria, and the disease may undergo spontaneous remission with some recovery, a condition rarely seen in subacute combined degeneration before the days of treatment with liver.

\section{Neurotropic Viruses}

Much study has been devoted during recent years to the mode of attack by neurotropic viruses on nerve cells. Their grosser effects in causing total destruction of the cells, either with or without neuronophagia, has been known for many years, and the older conception of a primarily inflammatory or vascular reaction with secondary affection of the neurone has been entirely abandoned. In rabies this newer view is old enough. It was indicated by the discovery by Negri (1903) of the inclusion bodies characteristic of the disease, and was established by the classical studies of Achucarro (1910). In the epidemic of encephalitis lethargica it soon became evident that certain systems of neurones, especially those of the substantia nigra, were primarily affected and often degenerated rapidly and disappeared without neuronophagia and with comparatively little inflammatory or vascular disturbance in their neighbourhood. Later studies of Borna disease by Nicolau, Dimanesco-Nicolau, and Galloway (1929), of poliomyelitis by Weston Hurst (1929-31), and of other virus diseases of the nervous system, have not only confirmed this view, but have added many histological details indicating the manner in which the neurone is attacked.

Achucarro's studies were remarkable both for their completeness and also for the accuracy with which he described changes in the neurone which have been found to be common in greater or less degree to all diseases caused by neurotropic viruses. In addition to giving a fuller description of the inclusion bodies which Negri had described, he studied the neurofibrils and the Nissl granules and gave the first description of the early changes in the nucleus. He confirmed Cajal's (1904a) finding of early thickening and later dissolution of the neurofibrils which Hurst later found also in the early stages of poliomyelitis. The early nuclear changes which he described consisted of swelling and diffuse appearance of the acidophil elements with fragmentation of the basophil chromatin. These changes might precede any obvious disturbance in the cell body. Later with the disappearance of the nuclear membrane various degenerative changes were found in the cell body.

Somewhat similar nuclear changes were described by Lipschutz (1921) and confirmed by Goodpasture (1925) in the nerve cells in experimental herpes encephalitis. In this disease the earlier stage of swelling and greater intensity of staining of the acidophil elements does not appear to progress to the formation of more definite intranuclear bodies. In poliomyelitis Covell (1930) 
demonstrated the formation of small, strongly acidophil intranuclear bodies, and Weston Hurst (1931a) later confirmed this and described the various stages in their formation.

The intra-nuclear inclusion bodies described in Borna disease by Joest and Degen (1911) and later studied more extensively by Nicolau and Galloway appear to be of very similar origin, but differ from most other bodies of this kind in showing a clear halo round the oxyphil granules. Similar oxyphil intranuclear bodies have been described in yellow fever, pseudorabies, equine encephalomyelitis, and other forms of virus encephalitis in animals.

In all these diseases oxyphil intranuclear bodies are found only in cells which are relatively little affected, although they may show chromatolysis and other degenerative changes of the cytoplasm. In cells which are obviously dead and which are undergoing neuronophagia the nucleolus and chromatin have usually disappeared and the nucleus may stain diffusely with acid dyes, but no structures resembling inclusion bodies can be seen. In Borna disease Nicolau and Galloway postulated that the presence of inclusion bodies, indicated the victory of the nerve cell in its fight with the virus, and the finding by Hosselet and Erbes (1935) of inclusion bodies in a large proportion of the dorsal root ganglion cells in poliomyelitis supports this view. Hurst, however, is somewhat doubtful of its universal application, seeing that many nerve cells which contain nuclear inclusions are obviously degenerated.

Intranuclear inclusions may be single or multiple, according to the disease in which they are found. Those of Borna disease are often single, whereas in poliomyelitis, pseudorabies, and yellow fever they are always multiple. They are often associated with fragmentation of the nucleolus and margination of the nuclear chromatin.

There has been some controversy as to whether they are sufficiently specific to be regarded as evidence of the presence of the virus in the nerve cells, as somewhat similar appearances have been seen in brain tumours and many pathological conditions. Hurst (1934) has pointed out that these appearances can also be seen in normal nerve cells under special conditions of fixation and staining, but they differ from the true nuclear inclusions in appearing less solid and sharply defined and less brilliantly stained with acid dyes, and often also in showing little projections uniting them to the general, weakly acidophil, nuclear reticulum. "They never show evidence of internal heterogeneity, as do frequently the bodies described as nuclear inclusions." Nor do the nuclei containing them show other evidences of degeneration.

If nuclear inclusions are evidence of the penetration of virus into nerve cells we should expect them to bear some relationship to the better known cytoplasmic inclusions, such as Negri bodies. The origin of these had given rise to much controversy. They have been considered, especially by Levaditi and his co-workers (1926) to constitute a phase of the parasite Glugea Lyssæ. Goodpasture considered the smaller lyssa bodies and the acidophil part of the Negri bodies to arise from degeneration of the neurofibrils, and the basophil " inner bodies" from degeneration of mitochondria. However, a number of workers (Lentz, 1909 ; Benedek, 1921 ; Suzuki, 1930) have postulated an 
origin from the nuclear sap. Marinesco and Stroesco (1931) found them to contain neither nucleic acid nor iron, which was definite proof that they did not constitute an intra-cellular parasite of the glugeid family. On the other hand, they found definite evidence that they were derived from the nucleus. They found in rabies nuclear inclusions very similar to those seen in other virus diseases, such as poliomyelitis and Borna disease, and postulated that these bodies passed through the nuclear membrane into the cytoplasm, where they enlarged into the typical Negri body.

Cytoplasmic inclusions have also been found by Weston Hurst (1931b) in mice infected with "louping ill," and in them at least no nuclear inclusions could be seen. Therefore, although Marinesco's theory of the origin of Negri bodies from nuclear constituents is attractive in bringing rabies into line with other virus diseases of the nervous system, it cannot be considered as proved. Covell and Danks (1932) do not support his findings otherwise, as they obtained a weak Feulgen reaction for nucleic acid in some of the Negri bodies, and saw evidence of iron in them in ashed sections.

The controversy that has raged round these bodies has been valuable at least in diverting attention from the obvious inflammatory changes associated with virus disease of the nervous system to the finer but more specific reaction which they cause in the nerve cell. As Spielmeyer (1929) has insisted, inflammatory and neuroglial reactions in the nervous system are limited in type and may be the same in diseases of very different ætiology, or may vary greatly from case to case in the same disease. To some extent this may also be true for the reactions of the neurone, but many of the changes seen in it are so closely related to the disease in which they occur as to be almost specific, e.g. the changes seen in such conditions as amaurotic idiocy, Alzheimer's disease, disseminated sclerosis, and subacute combined degeneration.

\section{REFERENCES}

Achucarro, N. (1910). Nissl. Alzheimer Arbeiten, 3, 143.

Alexander, L. (1938). Brain, 61, 52.

Alexander, L., and Myerson, A. (1937a). Amer. J. Path., 13, 405.

- $(1937 b)$. Arch. Neurol. Psychiat. Chicago, 39, 131.

Arnell, N. (1936). Acta Psychiat. Neurol., 11, 5.

Balado, M., and Francke, E. (1937). Arch. argent. Neurol., 17, 35.

Beams, H. W., and King, R. L. (1935). J. comp. Neurol., 61, 175.

Benedek, L., and Porsche, F. O. (1921). Vber die entstehung aer Negrischen Korperchen Berlin.

Bertrand, I., and Hadzigeorgiou (1927). Ann. Anat. path. méd. chir., 5, 461.

Bertrand, I., Liber, A. F., and Randoin (1934). Arch. Anat. micr. 30, 297.

Cajal, S. Ramon (1891). Rev. Cienc. méd. Barcelona, Nos. 22 and 23.

- (1904). Trab. Lab. Invest. biol. Univ. Madr., 3, 287.

- (1913-14). Estudios sobre la degen. y regen. del systema nervioso. Madrid.

- (1928). Degeneration and Regeneration of the Nervous System. Oxford.

Choja, N. (1936). Mitt. med. Akad. Kioto., 17, 990 ; 18, 322, 793, 1714.

Clark, W. E. le G. (1932). Brit. J. Ophthal., 16, 264.

Clark, W. E. le G., and Penman, G. G. (1931). Proc. roy. Soc., 114.

Clarke, J. M. (1904). Brain, 27, 441.

Covell, W. P. (1930). Proc. Soc. exp. Biol. Med., 27, 927.

Covell, W. P., and Danks, W. B. C. (1932). Amer. J. Pathol., 8, 557.

Cowdry, E. V. (1912). Int. Mschr. Anat. Physiol., 29, 443. 
Cowdry, E. V. (1932). Penfield's Cytology and Cellular Pathology of the Nervous System. Hoeber, New York.

Davison, C. (1934). J. Neurol. Psychopath., 14, 227.

Donaldson, H. H., and Hoke, G. W. (1905). J. comp. Neurol., 15,

Duncan, D. (1934). Ibid., $60,437$.

Dustin, - (1910). Arch. Biol., 25,

Einarson, L. (1935). J. comp. Neurol., 61, 101.

Eveleth, D. F., and Biester, H. E. (1937). Amer. J. Pathol., 13, 257.

Fedorow, B. G. (1935). Trab. Lab. Invest. biol. Univ. Madr., 30, 403.

Foerster, O., and Gagel, O. (1934). Z. mikr.-anat. Forsch., 36, 567.

Ford, F. R. (1928). Johns Hopk. Hosp. Bull., 42, 70.

Gildea, E. F., and Cobb, S. (1930). Arch. Neurol. Psychiat. Chicago, 23, 876.

Goldberger, J., Wheeler, G. A., Lillie, R. D., and Rogers, L. M. (1928). U.S.A. Public Health Reports, 43, 687 and 1,385.

Gomez, L., and Pike, F. H. (1909). J. exp. Med., 11, 257.

Goodpasture, E. W. (1925). Amer. J. Path., 1, 1,547.

Gramenitsky, M. (1934a). Abderhaldens Handb. ArbMeth., 5, 8. (1934b). Z. Zellforsch., 21,

Greenfield, J. G., and Carmichael, E. A. (1935). Brain, 52, 483.

and O'Flynn, E. (1933). Lancet, ii, 62.

Hamerton, A. E. (1936). Proc. Zool. Soc. Lond., 659. (1937). Ibid., Series B., 443.

Hechst, B. H. (1933). Arch. Psychiat. Nervenkr., 100, 19.

Hosselet, C., and Erber, B. (1935). C. R. Soc. Biol., 118, 1,387.

Hurst, E. W. (1929). J. Path. Bact., 32, 457.

- (1931a). Ibid., 34, 331 .

- (1931b). J. comp. Path., 44, 231. (1936). Brain, 59, 1.

Ingvar, S. (1923). Arch. Neurol. Psychiat. Chicago, 10, 267.

Jacobi, J., and Keuscher, W. (1927).

Joest, E. (1911). Dtsch. Z. nervenheilk., 42, 293.

Kedrowski, B. (1935). Arch. Anat. micr., 31, 451.

Langworthy, O. (1931). Brain, 54, 291.

Lentz, O. (1909). Z. Hyg. InfektKr., 62, 63.

Levaditi, C., Lepine, P., and Schoen, R. (1930). C. R. Soc. Biol., 104, 986.

Levaditi, G., Nicolau, S., and Schoen, R. (1926). Ann. Inst. Pasteur, 40, 973.

Levi, G., and Meyer, H. (1937). Anat. Anz., 83, 401.

Lipschutz, B. (1921). Zbl. Bakt., 87, 303.

Macallum, A. B. (1898). Brit. med. J., 11, 778.

Mackenzie, J. J. (1897). Rep. Brit. Ass. Toronto, 822.

Marinesco, G. (1909). La cellule nerveuse, Doin, Paris. (1911). C. R. Soc. Biol., 70, 1,057. (1930). J. Psychol. Neurol., Lpz., 41, 1.

Marinesco, G., and Stroesco, G. (1931). Arch. roum. Path. exp. Microbiol., 4, 243.

Mellanby, E. (1931). Brain, 54, 247.

Minowski, (1920). Schweiz. Arch. Neurol. Psychiat., 6, 7.

Mott, F. W. (1911). Introduction to neuropathology in Allbutt and Rolleston's System of Medicine, 2 nd edition. (1912). Brit. med. J., 11, 780.

Nageotte, J. (1912). Arch. mikr. Anat., 77, 245. (1914). Rev. Neurol., 11, 505.

Negri, A. (1903). Z. Hyg. InfektKr., 43, 567.

Nicolau, S. D., Nicolau, O., and Galloway, I. A. (1929). Ann. Inst. Pasteur., 43, 1.

Nicholson, F. M. (1923). J. comp. Neurol., 36, 37.

Penfield, W. G. (1920). Brain, 43, 290.

Pentschew, A. (1929). Z. ges. Neurol. Psychiat., 118, 17.

Perdrau, J. R. (1930). J. Path. Bact., 32, 991.

- (1937). Brain, 60, 204.

Peterfi, - (1929). Arch. exp. Zellforsch., 11, 302.

Peters, R. A. (1936). Lancet, 1, 1161.

de Renyi, G. S. $(1929 a)$. J. comp. Neurol., 47, 405.

- (1929b). Ibid., 48, 293, 441.

- (1931). Ibid., 53, 497. (1932). Cowdry's Special Cytology, 2nd edition, 3, 1,369.

Russell, J. S. R., Batten, F. E., and Collier, J. S. (1900). Brain, 23, 39.

Scherer, H. J. (1932). Z. ges. Neurol. Psychiat., 141, 212. (1937). Rev. Neurol., 68, 807.

Schob, F. (1931). Z. ges. Neurol. Psychiat., 135, 95.

Speidel, C. C. (1935). J. comp. Neurol., 61, 1. 
Spielmeyer, W. (1929). Dtsch. Z. Nervenheilk., 110,

(1930). Arch. Neurol. Psychiat. Chicago., 23, 869.

Stern, R. O., and Findlay, G. M. (1929). J. Path. Bact., 32, 63.

Suzuki, N. (1930). Z. ges. Neurol. Psychiat., 125, 163.

Tello, F. (1904). Trab. Lab. Invest. biol. Univ. Madr., 3, 113.

Thenon, J., and Pirosky, I. (1937). Encéphale., 32, 159.

Tureen, L. L. (1936). Arch. Neurol. Psychiat. Chicago, 35, 789. (1938). Ibid., 39, 455.

de Villaverde, J. M. (1926). Trab. Lab. Invest. biol. Univ. Madr., 24, 1.

Weimann, W. (1925). Z. ges. Neurol. Psychiat., 98, 347.

Weiss, P., and Wang, H. (1936). Anat. Rec., 67, 105.

Zimmerman, H. M. (1937). Schweiz. Arch. Neurol. Psychiat., 39, 195.

Zimmerman, H. M., and Burack, E. (1934). J. exp. Med., 59, 21. 